\title{
Role of Alvarado score and biological indicators of C-reactive protein, procalicitonin and neopterin in diagnosis of acute appendicitis
}

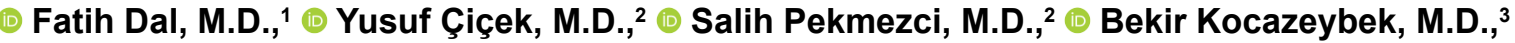 \\ ๑ Hrisi Bahar Tokman, M.D., ${ }^{3} \odot$ Dildar Konukoğlu, M.D.,4 ${ }^{4}$ Osman Şimşek, M.D., ${ }^{2}$ \\ (ㄱ) Zeynep Taner, M.D., ${ }^{3}$ ๑ Serhat Sirekbasan, M.D., ${ }^{3}$ ○ Server Sezgin Uludağ, M.D. ${ }^{2}$
}

\begin{abstract}
1'Department of General Surgery, University of Health Sciences İstanbul Training and Research Hospital, İstanbul-Turkey ${ }^{2}$ Department of General Surgery, İstanbul University-Cerrahpaşa, Cerrahpaşa Faculty of Medicine, İstanbul-Turkey ${ }^{3}$ Department of Medical Microbioloji, İstanbul University-Cerrahpaşa, Cerrahpaşa Faculty of Medicine, İstanbul-Turkey ${ }^{4}$ Department of Biochemistry, İstanbul University-Cerrahpaşa, Cerrahpaşa Faculty of Medicine, İstanbul-Turkey
\end{abstract}

\begin{abstract}
BACKGROUND: The determination of a definitive preoperative diagnosis of acute appendicitis (AA) remains a challenge; however, delays in diagnosis increase complication rates. The aim of this study was to investigate the contribution of the Alvarado score (AS) alone and the AS combined with the use of the biological indicators of C-reactive protein (CRP), procalcitonin (PCT) and neopterin (NP) in the diagnosis.

METHODS: Serum was collected from 100 patients who were admitted to the general surgery clinic of Istanbul University, Cerrahpasa Medical Faculty between March 4, 2014 and July 29, 2015 with the pre-diagnosis of AA and who agreed to take part in the study. The serum samples were stored at $-70^{\circ} \mathrm{C}$. The patients were divided into 2 groups: AA-positive $(n=60)$ and $A A-n e g a t i v e ~(n=40)$. The AA positive group was divided into subgroups of complicated $(n=11)$, uncomplicated AA $(n=49)$ and the AS, CRP, PCT, NP levels were compared.

RESULTS: The study population consisted of 45 men (45\%) and 55 women (55\%), with a mean age of $32.8 \pm 13.7$ years (range: 18-92 years). There was no significant difference between the groups in age and gender. There were 24 patients with an AS $\leq 4$ (3 had surgery), 35 patients with an AS of 5-7 (22 had surgery), and 4I patients with an AS of 8-10 (38 had surgery). Three of the 63 patients who underwent surgery were diagnosed with a normal appendix. The serum CRP, PCT, and NP measures were found to be inadequate to make an AA diagnosis alone, these values increased the sensitivity and specificity of the AS. The biological indicators were also significant in differentiating between the complicated and uncomplicated AA groups $(p<0.05)$.
\end{abstract}

CONCLUSION: Although the AS is useful, additional testing and clinical approaches are valuable to inform the diagnostic procedure. When considered alone, serum CRP, PCT and NP values are insufficient for a diagnosis of AA. However, they increased the diagnostic value of the AS and can be helpful in distinguishing complicated AA cases.

Keywords: Acute appendicitis; Alvarado score; C-reactive protein; neopterin; procalcitonin.

\section{INTRODUCTION}

Acute appendicitis (AA) is one of the most common causes of acute abdomen requiring surgical intervention. Approxi- mately $30 \%$ of patients present with atypical clinical symptoms. ${ }^{[l]}$ Anamnesis, physical examination, laboratory tests, imaging methods, and scoring systems are used to make a diagnosis of $A A \cdot{ }^{[2,3]}$ The Alvarado score (AS) is the most

Cite this article as: Dal F, Çiçek Y, Pekmezci S, Kocazeybek B, Bahartokman H, Konukoğlu D, et al. Role of Alvarado score and biological indicators of C-reactive protein, procalicitonin and neopterin in diagnosis of acute appendicitis. Ulus Travma Acil Cerrahi Derg 2019;25:229-237.

Address for correspondence: Fatih Dal, M.D.

Sağlık Bilimleri Üniversitesi, İstanbul Eğitim ve Araştırma Hastanesi, Genel Cerrahi Kliniği, İstanbul, Turkey

Tel: +90 212 - 5884400 E-mail: fatihdal07@gmail.com

Ulus Travma Acil Cerrahi Derg 2019;25(3):229-237 DOI: 10.5505/tjtes.2018.57362 Submitted: 23.06.2018 Accepted: 22.10.2018 Online: I5.05.2019

Copyright 2019 Turkish Association of Trauma and Emergency Surgery 
commonly used scoring system for the diagnosis of appendicitis. The components of the Alvarado score are migration of pain, anorexia, nausea-vomiting, right lower quadrant tenderness (RLQT), rebound, temperature $\geq 37.3^{\circ} \mathrm{C}$, leukocytosis, and increased neutrophilia. RLQT and leukocytosis score 2 points, while other parameters score I point. ${ }^{[1-3]}$ In many studies, it has been recommended that patients with an AS $\leq 4$ be discharged, those with an AS of 5-7 be monitored for 24 hours, and patients with an AS of 8-10 undergo surgery. ${ }^{[3-6]}$

Fever, white blood cell (WBC) count, sedimentation rate, Creactive protein (CRP) level, and procalcitonin (PCT) level are reliable parameters used in the diagnosis of acute bacterial infections. The serum level of PCT concentration changes with the inflammatory reaction, and an operative intervention and antibiotherapy can reduce the PCT level. ${ }^{[7-9]}$ Transplantation, which is associated with cellular immunity activity, is known to increase serum neopterin (NP) in some clinical scenarios, such as viral diseases. ${ }^{[10]}$

Despite current advanced methods, it is still challenging to make a certain AA diagnosis. ${ }^{[3]}$ The objective of this study was to investigate the contribution of the AS and the biomarkers of CRP, PCT and NP when used alone or together to diagnose AA.

\section{MATERIALS AND METHODS}

This study was conducted with the approval of the Istanbul University Cerrahpaşa Medical Faculty Ethics Committee (no. $88931902 / 262$ dated 21.01.2014). The study included a total of 100 patients who presented at the emergency service of the general surgery department between March 4, 2014 and July 29, 2015 with suspected AA and who gave written consent for inclusion in the study. The criteria for the study were age over 18 years and the presence of complaints for more than 12 hours. Patients who were pregnant, younger than 18 years of age, those who had chronic renal failure, chronic viral disease, autoimmune disease or did not give consent to participate were excluded from the study.

Medical care and monitoring was provided to the patients by an independent physician who was associated with the study. Patients who did not undergo surgery were monitored for 24-hours. Patient data, including AS, age, gender, CRP level and the duration of abdominal pain, were recorded on admission. To assess the PCT and NP, serum samples were collected from all of the patients and stored at $-70{ }^{\circ} \mathrm{C}$. Fluid samples were collected at the start of the surgeryafter irrigation of the periappendiceal area with $10 \mathrm{cc}$ of normal saline. A culture test was also performed.

Patients who were monitored in the ward for 24-hours after the first examination and discharged due to the regression of complaints were clinically regarded as AA-negative.
Those who were assessed to have a normal appendix according to the pathology evaluation and discharged after observation were classified as AA-negative, whereas patients determined to have appendicitis in the histopathological examination were classified as AA-positive. Patients with histopathologically determined AA were divided into subcategories of uncomplicated AA (phlegmonous appendicitis) and complicated (gangrene or perforated appendicitis) AA cases (Fig. I).

At the end of the study, PCT was evaluated using the Brahms PCT sensitive Kryptor kit (Thermo Fisher Scientific, Inc., Waltham, MA, USA) with a $50 \mu \mathrm{L}$ sample volume at the Istanbul University Cerrahpaşa Medical Faculty biochemistry laboratory and NP was assessed using the DRG Neopterin 96-test (DRG International, Inc., Springfield Township, NJ, USA) at the microbiology laboratory. The thresholds of 5 $\mathrm{mg} / \mathrm{L}, 0.5 \mathrm{ng} / \mathrm{mL}$, and $10 \mathrm{nmol} / \mathrm{L}$ were used to determine the sensitivity of CRP, PCT, and NP. Patients with an AS of $>7$ were regarded as AA-positive, while those with an AS of $\leq 7$ were considered AA-negative.

Mean, SD, median, minimum, maximum, frequency, and ratio values were used in the descriptive statistics of study data. Distribution of the variables was measured using the Kolmogorov Smirnov test. The Mann-Whitney $U$ test was used for the analysis of quantitative data. The effect and cut-off values were determined with a receiver operating characteristic curve. A kappa test was used to evaluate compliance. All of the analyses were conducted using SPSS Statistics for Windows, Version 22.0 (IBM Corp., Armonk, NY, USA).

\section{RESULTS}

A total of 100 patients who were admitted to the general surgery department and provided consent for the study were included in the study. Sixty-three (63\%) patients had laparoscopic surgery due to AA, whereas 37 (37\%) patients were discharged after 24 hours of follow-up and classified as AA-negative. Patients who were operated on with the prediagnosis of $A A$ were divided into 3 subgroups according to their pathology results: I) complicated AA (Atypical A.A) group, consisting of II patients (II\%) with perforated or gangrenous appendicitis, 2) uncomplicated AA group, comprising 49 (49\%) patients with phlegmonous appendicitis, and 3) AA-negative group, consisting of $3(3 \%)$ patients whose pathological examination demonstrated a normal appendix. In terms of clinical and pathological findings, 40 (40\%) of 100 patients were classified as AA-negative, while the remaining 60 patients (60\%) were AA-positive (Fig. I, Table I).

In this study group, 45 (45\%) patients were men and 55 $(55 \%)$ were women, and the mean age was $32.8 \pm 13.7$ years (range: 18-92 years) (Table I). The 60 patients clinically and histopathologically diagnosed with AA included 3 I (52\%) female and 29 (48\%) male patients with an aver- 


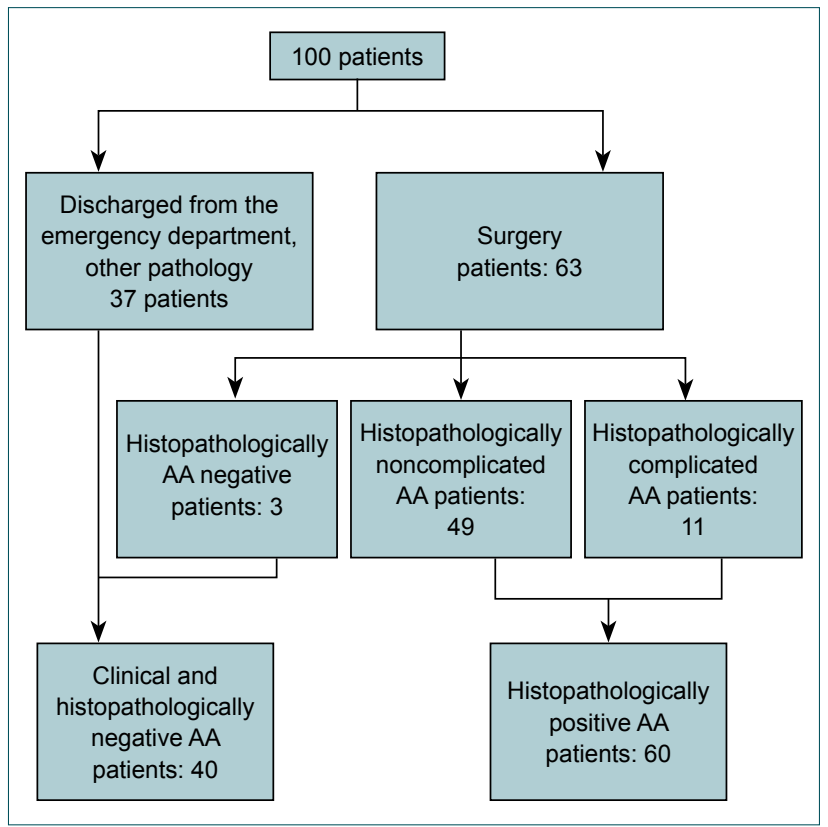

Figure 1. Distribution of patients.

age age of $32.3 \pm 12.8$ years. The mean duration of abdominal pain was $38.6 \pm 36.4$ hours. In the, group classified clinically and histopathologically as AA-negative, there were 24 $(60 \%)$ female and $16(40 \%)$ male patients. The mean age was $33.6 \pm 14.8$ years and the average duration of abdominal pain was $65.5 \pm 115$ hours in the AA-negative group. There was no statistically significant $(p>0.05)$ difference between the AAnegative and $A A$-positive patients in age, gender, or duration of abdominal pain (Table 2).

There were $6(55 \%)$ male and 5 (45\%) female patients in the complicated AA group, and the average age of the patients was $4 I \pm 18.2$ years. The uncomplicated AA group consisted of $23(47 \%)$ men and 26 (53\%) women, and the mean age was $30.3 \pm 10.5$ years. No significant difference was detected between the 2 groups regarding gender distribution ( $p>0.05)$. However, the patients in the uncomplicated AA group were significantly younger than the complicated AA patients $(p<0.05)$. It was estimated that the mean length of abdominal pain was $71.1 \pm 65.2$ hours for the complicated AA patients while it was $31.6 \pm 21.2$ hours for the non-complicated $A A$ cases. In other words, the duration of abdominal pain was significantly shorter among the non-complicated patients compared with the complicated patients (Table 4).

There were 24 patients with an AS of $\leq 4$ and 21 were discharged after 24 hours of follow-up while 3 patients underwent surgery and were confirmed to have AA by the histopathology test. Of the 35 patients with an AS of 5-7, 22 had surgery, while 13 were discharged after 24 hours of follow-up. Among the patients who underwent surgery, 3 had a normal appendix and 19 patients were diagnosed with AA in the histopathology examination. Of 4I AS 8-10 patients, 38 had surgery and all were diagnosed with AA
Table I. Average and distribution of demographic and variable data of the study population

\begin{tabular}{lccccc}
\hline & Min-Max & Median & Mean士SD & n & $\%$ \\
\hline Age & $18-92$ & 29 & $32.8 \pm 13.7$ & & \\
Patients & & & & & \\
$\quad$ Female & & & & 55 & 55.0 \\
$\quad$ Male & & & & 45 & 45.0
\end{tabular}

Abdominal pain

$\begin{array}{llll}\text { (hours) } \quad 12-720 & 24 & 49.4 \pm 78.6\end{array}$

Clinic+histopathology

Atypical AA

II 11.0

Phlegmonous

$\mathrm{AA}+\mathrm{AA}$

Negative

appendectomy

$3 \quad 3.0$

Other pathologies

$38 \quad 38.0$

Acute appendicitis

$(-)$

$40 \quad 40.0$

$(+)$

6060.0

Alvarado score $\quad 2.0-10.0 \quad 7.0 \quad 6.5 \pm 2.2$

Alvarado score

$\leq 4$

$24 \quad 24.0$

5-7

$35 \quad 35.0$

8-10

$\begin{array}{ll}41 & 41.0\end{array}$

Alvarado score

$<8$

$59 \quad 59.0$

8-10

$41 \quad 41.0$

$\mathrm{CRP}(\mathrm{mg} / \mathrm{L})$

CRP (mg/L)

$\leq 5$

$32 \quad 32.0$

$>5$

$68 \quad 68.0$

$\mathrm{NP}(\mathrm{nmol} / \mathrm{L})$

I.5-33.3 $3.0 \quad 4.6 \pm 4.9$

$\mathrm{NP}(\mathrm{nmol} / \mathrm{L})$

$\leq 10$

$91 \quad 91.0$

$>10$

$0.0-9.0$

0.1

99.0

\begin{tabular}{|c|c|c|}
\hline PCT $(\mathrm{ng} / \mathrm{mL})$ & $0.0-9.0$ & 0.1 \\
\hline PCT (ng/mL) & & \\
\hline
\end{tabular}

9393.0

$>0.5$

$\begin{array}{ll}7 & 7.0\end{array}$

AA: Acute appendicitis; CRP: C-reactive protein; NP: Neopterin; PCT: Procalcitonin; Min: Minimum; Max: Maximum; SD: Standard deviation.

through histopathology. However, additional tests demonstrated that 3 patients did not have $A A$, and they were discharged after 24 hours of monitoring. The average AS was $4.7 \pm 1.7$ in the AA-negative group $(n=40)$ and $7.7 \pm 1.5$ in patients who had histopathologically positive AA $(n=60)$ (Tables 1-3). 
Table 2. Comparison of acute appendicitis positive and negative groups in terms of age, gender, and abdominal pain

\begin{tabular}{|c|c|c|c|c|c|}
\hline & \multicolumn{2}{|c|}{ Acute appendicitis (-) } & \multicolumn{2}{|c|}{ Acute appendicitis (+) } & \multirow[t]{2}{*}{$\mathbf{p}$} \\
\hline & Mean \pm SD & Med (Min-Max) & Mean \pm SD & Med (Min-Max) & \\
\hline Age (years) & $33.6 \pm 14.8$ & $29(18-92)$ & $32.3 \pm 12.8$ & $30(18-85)$ & 0.952 \\
\hline \multicolumn{6}{|l|}{ Patients, n (\%) } \\
\hline Female & $24(60)$ & & $31(52)$ & & 0.412 \\
\hline Male & $16(40)$ & & $29(48)$ & & \\
\hline Abdominal pain (hours) & $65.5 \pm 115.0$ & $33(12-720)$ & $38.6 \pm 36.4$ & $24(12-192)$ & 0.062 \\
\hline
\end{tabular}

Mann-Whitney U Test / Chi-square test. Min: Minimum; Max: Maximum; SD: Standard deviation.

Table 3. Comparison of variable data of acute appendicitis positive and negative groups

\begin{tabular}{|c|c|c|c|c|c|}
\hline & \multicolumn{2}{|c|}{ Acute appendicitis (-) } & \multicolumn{2}{|c|}{ Acute appendicitis (+) } & \multirow[t]{2}{*}{$\mathbf{p}$} \\
\hline & Mean \pm SD & Med (Min-Max) & Mean $\pm S D$ & Med (Min-Max) & \\
\hline Acute appendicitis & $4.7 \pm 1.7$ & $4.0(2.0-8.0)$ & $7.7 \pm 1.5$ & $8.0(4.0-10.0)$ & 0.000 \\
\hline C-reactive protein $(\mathrm{mg} / \mathrm{L})$ & $22.4 \pm 32.6$ & $10.5(0.2-129.0)$ & $56.4 \pm 77.7$ & $29.2(0.4-333.0)$ & 0.008 \\
\hline Neopterin (nmol/L) & $4.3 \pm 5.2$ & $2.8(1.7-33.3)$ & $4.8 \pm 4.7$ & $3.3(1.5-29.1)$ & 0.107 \\
\hline Procalcitonin (ng/mL) & $0.1 \pm 0.1$ & $0.0(0.0-0.5)$ & $0.6 \pm 1.6$ & $0.1(0.0-9.0)$ & 0.000 \\
\hline
\end{tabular}

Mann-Whitney U Test / Chi-square test. Min: Minimum; Max: Maximum; SD: Standard deviation.

Table 4. Comparison of complicated and uncomplicated acute appendicitis groups

\begin{tabular}{|c|c|c|c|c|c|}
\hline & \multicolumn{4}{|c|}{ Histopathologically acute appendicitis positive group } & \multirow[t]{3}{*}{$\mathbf{p}$} \\
\hline & \multicolumn{2}{|c|}{ Complicated acute appendicitis } & \multicolumn{2}{|c|}{ Uncomplicated acute appendicitis } & \\
\hline & Mean \pm SD & Med (Min-Max) & Mean $\pm S D$ & Med (Min-Max) & \\
\hline Age & $41.0 \pm 18.2$ & $39(22-85)$ & $30.3 \pm 10.5$ & $28.5(|8-6|)$ & 0.032 \\
\hline \multicolumn{6}{|l|}{ Patients, n (\%) } \\
\hline Female & $5(45)$ & & $26(53)$ & & 0.692 \\
\hline Male & $6(55)$ & & $23(47)$ & & \\
\hline Abdominal pain time & $7 I .1 \pm 65.2$ & $48(17-192)$ & $31.6 \pm 21.2$ & $24(12-96)$ & 0.034 \\
\hline Alvarado score & $8.2 \pm 1.4$ & $8(6-10)$ & $7.6 \pm 1.6$ & $8(4-10)$ & 0.403 \\
\hline C-reactive protein (mg/L) & $110.4 \pm 98.4$ & $107(5-330)$ & $44.4 \pm 68.5$ & $21.6(0-333)$ & 0.005 \\
\hline Neopterin (nmol/L) & $6.3 \pm 5.1$ & $3.83(3-16.59)$ & $4.5 \pm 4.6$ & $3.14(2-29.1115)$ & 0.049 \\
\hline Procalcitonin (ng/mL) & $1.1 \pm 1.9$ & $0.2(0-6.227)$ & $0.5 \pm 1.6$ & $0.07(0-8.974)$ & 0.001 \\
\hline \multicolumn{6}{|c|}{$\begin{array}{l}\text { E. coli culture positivity of } \\
\text { peri-appendicular sample, } n(\%)\end{array}$} \\
\hline E. coli (-) & $6(54.5)$ & & $36(75.0)$ & & 0.177 \\
\hline E. coli $(+)$ & $5(45.5)$ & & $12(25.0)$ & & \\
\hline
\end{tabular}

Mann-Whitney U Test / Chi-square test. Min: Minimum; Max: Maximum; SD: Standard deviation.

The mean CRP level was $42.8 \pm 65.6 \mathrm{mg} / \mathrm{L}$ (range: $0.2-333$ $\mathrm{mg} / \mathrm{L})$ for the study group $(\mathrm{n}=100)$. In all, $68(68 \%)$ patients had a CRP of $>5 \mathrm{mg} / \mathrm{L}$, and 32 (32\%) patients had a CRP of $\leq 5 \mathrm{mg} / \mathrm{L}$ (Table I). The mean CRP value was significantly higher in the $A A$-positive group than in the $A A$-negative group $(22.4 \pm 32.6 \mathrm{mg} / \mathrm{L}$ and $56.4 \pm 77.7 \mathrm{mg} / \mathrm{L}$, respectively; $\mathrm{P}<0.05$ ) (Table 3). The mean CRP level in the uncomplicated and complicated AA groups was $44.4 \pm 68.5 \mathrm{mg} / \mathrm{L}$ and 
Table 5. Reference cutoff values and ROC curve results for Alvarado scoring, C-reactive protein, neopterin, and procalcitonin

\begin{tabular}{|c|c|c|c|c|}
\hline & \multirow[t]{2}{*}{ Area under the curve } & \multicolumn{2}{|c|}{ Confidence interval } & \multirow[t]{2}{*}{$\mathbf{p}$} \\
\hline & & Lower limit & Upper limit & \\
\hline Alvarado scoring & 0.902 & 0.842 & 0.961 & 0.000 \\
\hline Alvarado scoring cutoff value: 8 & 0.779 & 0.687 & 0.871 & 0.000 \\
\hline C-reactive protein (mg/L) & 0.657 & 0.550 & 0.765 & 0.008 \\
\hline C-reactive protein cutoff value: 5 & 0.588 & 0.472 & 0.703 & 0.140 \\
\hline Neopterin (nmol/L) & 0.595 & 0.479 & 0.712 & 0.107 \\
\hline Neopterin cutoff value: 10 & 0.513 & 0.397 & 0.628 & 0.833 \\
\hline Procalcitonin (ng/mL) & 0.718 & 0.613 & 0.822 & 0.000 \\
\hline Procalcitonin cutoff value: 0.5 & 0.558 & 0.445 & 0.671 & 0.325 \\
\hline
\end{tabular}

Table 6. Sensitivity and specificity of Alvarado scoring, $C$ reactive protein, neopterin, and procalcitonin in diagnosis of acute appendicitis

\begin{tabular}{|c|c|c|c|c|c|c|c|c|c|}
\hline & & AA (-) & $A A(+)$ & Sensitivity (\%) & PPV (\%) & Specificity (\%) & NPV (\%) & Kappa & $\mathbf{p}$ \\
\hline \multirow[t]{2}{*}{ AS } & $\leq 7$ & 37 & 22 & 63 & 93 & 93 & 63 & 0.517 & 0.000 \\
\hline & $>8$ & 3 & 38 & & & & & & \\
\hline \multirow[t]{2}{*}{ CRP (mg/L) } & $\leq 5$ & 17 & 15 & 75 & 66 & 43 & 53 & 0.181 & 0.066 \\
\hline & $>5$ & 23 & 45 & & & & & & \\
\hline \multirow[t]{2}{*}{ NP (nmol/L) } & $\leq 10$ & 37 & 54 & 10 & 67 & 93 & 41 & 0.021 & 0.669 \\
\hline & $>10$ & 3 & 6 & & & & & & \\
\hline \multirow[t]{2}{*}{ PCT (ng/mL) } & $\leq 0.5$ & 40 & 53 & 12 & 100 & 100 & 43 & 0.096 & 0.025 \\
\hline & $>0.5$ & 0 & 7 & & & & & & \\
\hline \multirow[t]{2}{*}{ ASV CRP } & $(-)$ & 17 & 6 & 90 & 70 & 43 & 74 & 0.350 & 0.000 \\
\hline & $(+)$ & 23 & 54 & & & & & & \\
\hline \multirow[t]{2}{*}{ ASVNP } & $(-)$ & 34 & 21 & 65 & 87 & 85 & 62 & $0.47 I$ & 0.000 \\
\hline & $(+)$ & 6 & 39 & & & & & & \\
\hline \multirow[t]{2}{*}{ ASVPCT } & $(-)$ & 37 & 21 & 65 & 93 & 93 & 64 & 0.535 & 0.000 \\
\hline & $(+)$ & 3 & 39 & & & & & & \\
\hline \multirow[t]{2}{*}{$A S^{\vee} C R P \vee N P$} & $(-)$ & 17 & 6 & 90 & 70 & 43 & 74 & 0.350 & 0.000 \\
\hline & $(+)$ & 23 & 54 & & & & & & \\
\hline \multirow[t]{2}{*}{$A S \vee C R P \vee P C T$} & $(-)$ & 17 & 6 & 90 & 70 & 43 & 74 & 0.350 & 0.000 \\
\hline & $(+)$ & 23 & 54 & & & & & & \\
\hline \multirow[t]{2}{*}{ ASVPCTVNP } & $(-)$ & 34 & 21 & 65 & 87 & 85 & 62 & $0.47 I$ & 0.000 \\
\hline & $(+)$ & 6 & 39 & & & & & & \\
\hline \multirow[t]{2}{*}{$A S \vee C R P \vee N P \vee P C T$} & $(-)$ & 17 & 6 & 90 & 69 & 41 & 74 & 0.350 & 0.000 \\
\hline & $(+)$ & 24 & 54 & & & & & & \\
\hline
\end{tabular}

Kappa compliance test. AA: Acute appendicitis; PPV: Positive predictive value; NPV: Negative predictive value; AS: Alvarado score; CRP: C-reactive protein; NP: Neopterin; PCT: Procalcitonin.

I 10.4 $\pm 98.4 \mathrm{mg} / \mathrm{L}$, respectively. That is, the mean CRP was significantly higher in the complicated AA group $(p<0.05)$ (Table 4).

The mean NP value was $4.6 \pm 4.9 \mathrm{nmol} / \mathrm{mL}$ (range: I.5-33.3 $\mathrm{nmol} / \mathrm{L}) ; 9$ (9\%) patients had an NP of $>10 \mathrm{nmol} / \mathrm{L}$ and $9 \mathrm{I}$ (91\%) had an NP of $\leq 10 \mathrm{nmol} / \mathrm{L}$ (Table I). The mean NP of the AA-negative group was $4.3 \pm 5.2 \mathrm{nmol} / \mathrm{L}$ and that of $\mathrm{AA}$ positive group was $4.8 \pm 4.7 \mathrm{nmol} / \mathrm{L}$. No significant difference was observed between the 2 groups ( $p>0.05$ ) (Table 3). It was determined that the mean NP was $4.5 \pm 4.6 \mathrm{nmol} / \mathrm{L}$ in the uncomplicated $A A$ group and $6.3 \pm 5.1 \mathrm{nmol} / \mathrm{L}$ in the complicated AA group. The mean NP value of the complicated AA group was significantly higher $(p<0.05)$ (Table 4$)$. 
The mean PCT value of the study patients was $0.4 \pm 1.3 \mathrm{ng} /$ $\mathrm{mL}$ (range: $0-9 \mathrm{ng} / \mathrm{mL}$ ). In all, 7 (7\%) patients had a PCT of $>0.5 \mathrm{ng} / \mathrm{mL}$ and 93 (93\%) had a PCT of $\leq 0.5 \mathrm{ng} / \mathrm{mL}$ (Table I). The mean PCT of the AA-positive group was significantly higher than that of the AA-negative group $(0.6 \pm 1.6 \mathrm{ng} / \mathrm{mL}$ and $0.1 \pm 0.1 \mathrm{ng} / \mathrm{mL}$, respectively; $\mathrm{p}<0.05$ ) (Table 3). The mean PCT was $0.5 \pm 1.6 \mathrm{ng} / \mathrm{mL}$ in the uncomplicated AA group and $1 . I \pm 1.9 \mathrm{ng} / \mathrm{mL}$ in the complicated AA group. The complicated AA group had a significantly higher PCT $(p<0.05)$ (Table 4).

The AS cutoff score of 8 was significant $(p<0.05)$ in differentiating AA-negative and AA-positive patients; however, the cutoff values for CRP, NP, and PCT were insignificant $(p>0.05)$ (Table 5).

The AA-positive and AA-negative patients: C-reactive protein, procalcitonin, and neopterin, were evaluated separately and in the context of the AS. The AS [mean: 0.902 (range: $0.842-0.96 \mathrm{I}) ; \mathrm{p}<0.05$ ] and the AS cutoff value of 8 [mean: 0.779 (range: $0.687-0.871 ; p<0.05$ ] were seen to be effective (Table 5). The AS was found to have a sensitivity of $63 \%$, a specificity of $93 \%$, a positive predictive value of $93 \%$ and a negative predictive value of $63 \%$. The biological indicators of CRP, PCT, and NP were ineffective alone ( $p>0.05)$, but significantly influenced the sensitivity, specificity, positive predictive value, and negative predictive value of the AS when considered together (Table 6).

\section{DISCUSSION}

Anamnesis and physical examination are the basic tools used in the diagnosis of AA. Typical signs and symptoms of $A A$ were first reported by Heber Fitz in $1886 .{ }^{[1]}$ In cases of AA, the goal is to make a timely and correct diagnosis before the development of complications and to decrease the incidence of negative appendectomy. A number of methods have been suggested for this purpose. The AS, which was introduced in 1986, is widely used in clinical practice since it is easy, noninvasive, reproducible, and inexpensive. ${ }^{[4,6,12,13]}$

Since its introduction, the AS has been the focus of interest for many researchers. Douglas et al. ${ }^{[14]}$ did not perform surgical treatment in patients with an AS of $\leq 4$. Winn et al. ${ }^{[15]}$ discharged 12 AS $\leq 4$ patients after observation. When 2 of these 4 patients presented again, they performed surgery, but did not detect appendicitis. Winn et al. ${ }^{[5]}$ suggested that surgical intervention is not necessary for AS $\leq 4$ patients. Alvarado et al. ${ }^{[4]}$ reported that $80 \%$ of negative appendectomy patients had an AS of $<6$. They also argued that the use of the AS system can increase the reliability of diagnosis, especially in patients with different clinical conditions. Khan et al. ${ }^{[16]}$ discharged 17 AS $\leq 4$ patients. However, when 3 of these patients re-applied for treatment, researchers calculated the AS at 7, and therefore performed surgery. Many studies in the literature suggest that patients with an AS of $\leq 4$ be discharged; however, there are studies reporting on surgical treatment for $A S \leq 4$ patients. Yildirim et al. ${ }^{[5]}$ performed a surgical intervention for 14 of 18 patients with an AS of $\leq 4$ and observed AA in 13 of those patients. In their study of 313 cases, Yüksel et al. ${ }^{[6]}$ performed surgery for 23 of $60 \mathrm{AS} \leq 4$ patients. Of the 60 patients, 7 were discharged after monitoring. Yüksel et al. ${ }^{[6]}$ noted that if patients with an AS of $\leq 4$ are discharged without clinical follow-up, some AA cases may go unnoticed. Although there is no consensus in the literature on a clinical approach for AS $\leq 4$ patients, the relevant research shows that such patients are generally discharged. In our study, there were 24 patients with an AS of $\leq 4$; of those, 2 I patients were discharged and 3 were operated on. It is possible to encounter AA in AS $\leq 4$ patients. AA was identified in the histopathological examination of these 3 surgical patients. The AS $\leq 4$ patients suspected of AA should be observed for 24-hours. During that 24 hour follow-up period, the AS should be repeated and additional tests should be performed. If patients are to be discharged, they should be given appropriate guidance.

In the literature, there are distinct clinical approaches toward patients with an AS 5-7. Winn et al. ${ }^{[15]}$ treated 49 of 52 patients with an AS of 5-7 with antibiotics. Twenty seven patients re-applied to the clinic and 10 underwent surgery. Khan et al. ${ }^{[16]}$ reported that they discharged 22 of 3I AS 5-7 patients after a 24-hour follow-up period, but performed surgery for the other 9 patients. AA was confirmed in 6 of the 9 surgical patients.

Yildirim et al..$^{[5]}$ performed surgery for 62 of 70 patients with an AS of 5-7 and found a normal appendix in 3 patients. In a study of 55 AS 5-7 patients, Memon et al. ${ }^{[13]}$ reported that 50 patients were found to have AA and 5 patients had a normal appendix, and the authors underlined the importance of clinical experience in forming the diagnosis. Moreover, Yüksel et al. ${ }^{[6]}$ diagnosed 60 AA cases among 79 patients with an AS of 5-7. In the conclusion of that study, Yüksel et al. ${ }^{[6]}$ recommended that AS 5-7 patients should be assessed with consideration for the clinical findings, additional imaging methods should be employed in suspect cases, and decision making should include repeating the AS a few times at intervals. Uzunköy et al. ${ }^{[17]}$ stated that abdominal ultrasound with high sensitivity and specificity is an easy-to-use, repeatable, inexpensive, and non-invasive radiological examination alternative for additional testing in suspected cases of AA. Although there is no definitive clinical approach for AS 5-7 patients in the literature, conducting a 24-hour follow-up and performing additional examinations is the commonly accepted method when there is a suspicion of AA. In the present study, 22 of the 35 AS 5-7 patients underwent a surgical intervention, and 13 patients were discharged after being monitored for 24-hours. Among the patients who underwent surgery, 3 patients turned out to be AA-negative. However, AA was present in the remaining 19 patients. We believe that AS 5-7 patients with suspected AA should be subjected to a 24-hour monitoring period, during which the 
AS should be repeated and additional diagnostic tests should be performed as needed.

When it comes to patients with an AS of 8-10, Winn et al. ${ }^{[15]}$ operated on 52 of their 57 patients and detected AA in 47 patients. Khan et al. ${ }^{[16]}$ found AA in 45 of 52 AS 8-10 patients, while the appendix was normal in 7 patients. Yildirim et al. ${ }^{[5]}$ performed surgery on $5 \mathrm{I}$ of 55 patients with an AS of 8- 10 and found AA in 50 of the operated patients. Memon et al. ${ }^{[13]}$ operated on 4I AS 8-10 patients and detected AA in all cases. In the study conducted by Yüksel et al. ${ }^{[6]}$ a total of 110 patients with an AS of 8-10 had surgery and 97 of them were diagnosed with AA. In the literature, all of the researchers have recommended surgical intervention for AS 8-10 patients. In our study, 38 of 41 patients with an AS of 8-10 were operated on and all were diagnosed with AA through histopathological examination. In our opinion, surgery is recommended for patients with an AS of 8-10.

There are several biological markers that register an increase in the serum level during inflammatory reactions, the most known of which are CRP, PCT and NP. CRP values are commonly used in the diagnosis decision-making of patients with suspected AA. ${ }^{[18]}$ Albu et al. ${ }^{[19]}$ found that 56 patients being monitored with the pre-diagnosis of $A A$ had a serum CRP level of more than $2.5 \mathrm{mg} / \mathrm{L}$ and reported that CRP had $100 \%$ sensitivity, $84.6 \%$ specificity, $86.6 \%$ positive predictive value, and $100 \%$ negative predictive value. They argued that surgery can be postponed if the CRP level is below $2.5 \mathrm{mg} / \mathrm{L}$. In a study conducted by Kaya et al. ${ }^{[7]}$ with 78 patients, the CRP level increased in line with the severity of appendiceal inflammation, but such an increase in CRP was found to be ineffective in making a surgical intervention decision in AA cases. Peltola ${ }^{[8]}$ and Mikaelsson ${ }^{[20]}$ reported the positivity rate $(10 \mathrm{mg} / \mathrm{L}$ and $12 \mathrm{mg} / \mathrm{L}$ ) of CRP in cases with suspected AA to be $72 \%$ and $47 \%$, respectively. Some researchers argue that the CRP value is more useful than other indicators in predicting complicated appendicitis. ${ }^{[18]}$ Yang et al. ${ }^{[21]}$ analyzed 897 patients undergoing surgery due to suspected AA and found the mean CRP level to be $24.1 \mathrm{mg} / \mathrm{L}$ in inflammatory appendicitis cases and 96.8 $\mathrm{mg} / \mathrm{L}$ in perforated appendicitis cases.

Yildirim et al. ${ }^{[22]}$ indicated in an analysis of 85 patients who were operated on with a pre-diagnosis of AA that the mean CRP of non-complicated cases was $68.4 \pm 63.5 \mathrm{mg} / \mathrm{L}$ and that the mean of complicated cases was $135.9 \pm 53.8 \mathrm{mg} / \mathrm{L}$. In a study of 231 patients, Pruekprasert et al. ${ }^{[23]}$ found the sensitivity and specificity of CRP to be $62 \%$ and $56 \%$, respectively, when it is used along with the AS in the diagnosis of AA. They concluded that CRP measures may have a diagnostic value in forming the clinical diagnosis when considered together with the AS. Wu et al. ${ }^{[24]}$ analyzed 214 patients in their study and demonstrated that the AS is more effective than PCT or CRP values, but using PCT and CRP along with the AS may improve diagnostic success. Mengücük et al. ${ }^{[9]}$ reported in their study that included 100 patients that histopatho- logical findings of focal appendicitis, suppurative appendicitis, and perforated appendicitis had significantly higher PCT levels, and that patients with focal appendicitis, suppurative appendicitis, perforated appendicitis, abscess, or localized peritonitis had statistically significantly higher serum levels of CRP compared with patients discharged after follow-up. In the same study, Mengücük et al. demonstrated that the serum NP level was significant in patients histopathologically diagnosed with focal appendicitis, whereas it was not significant in plastron or perforated appendicitis cases. As a result of the study, Mengücük et al. argued that as the sensitivity and specificity of serum PCT, CRP, NP levels are low, they are not adequate (whether alone or used together) for diagnosis of AA. However, PCT, CRP, and NP can be regarded as clinical parameters to support the anamnesis and physical examination findings of patients. In this study, we respectively evaluated the reference values of inflammatory indicators suggested to be effective in differentiating AA-positive and AA-negative patients and observed that the cutoff value of 8 for the AS was significantly effective $(p<0.05)$. The AS had a sensitivity of $63 \%$, a specificity of $93 \%$, a positive predictive value of $93 \%$, and a negative predictive value of $63 \%$. When we investigated the use of positive reference values of the indicators (AS $>7$, CRP $>5 \mathrm{mg} / \mathrm{L}, \mathrm{PCT}>0.5 \mathrm{ng} /$ $\mathrm{mL}, \mathrm{NP}>10 \mathrm{nmol} / \mathrm{L}$ ) in differentiating the AA-positive and AA-negative patients, we observed that the serum levels of CRP, PCT, and NP were ineffective, while the AS was effective (Tables 3, 5, 6). The use of inflammatory indicators with the AS influences the sensitivity, specificity, positive predictive value, and negative predictive value of the AS. The highest sensitivity (90\%) was obtained when the

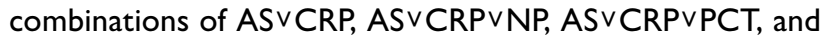

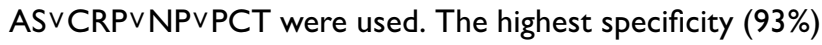
was observed with the combination of ASVPCT (Table 6). This study indicated that if a surgery decision is to be made for a patient with suspected AA considering the reference values, the AS itself is effective; however, the CRP, PCT, and NP values are not effective when used alone. On the other hand, these indicators impact the sensitivity and specificity of the AS in the diagnosis of AA. When the complicated and uncomplicated AA groups were compared with regard to the mean inflammatory indicators, the complicated AA group showed significantly higher results than the non-complicated AA group $(p<0.05)$ (Table 4). We believe that after the AA diagnosis has been established, the serum levels of CRP, PCT, and NP can be effective in differentiating complicated and uncomplicated AA patients.

\section{Conclusion}

In conclusion, $\mathrm{AA}$ is one of the common causes of acute abdomen in all age groups. Delays in diagnosis can elevate the rate of complications, which may result in increased morbidity and mortality. AA may be seen in patients with an AS of $\leq 4$. Suspected patients with an AS of $\leq 4$ and all patients with AS 5-7 should be followed-up for 24 hours with repeated 
AS evaluations and additional tests, if necessary. Surgery is important for AS 8-10 patients. Although the AS is a well-designed scoring system, additional diagnostic tests and clinical approaches are also needed in the diagnosis of AA. Serum levels of CRP, PCT, and NP alone are not adequate for an AA diagnosis; however, they are important indicators that increase the diagnostic value of the AS. The serum levels of CRP, PCT, and NP are also useful in distinguishing complicated and uncomplicated AA cases.

\section{Acknowledgment}

The authors would like to thank the Istanbul University Scientific Research Projects Unit.

\section{Conflict of interest: None declared.}

\section{REFERENCES}

1. Behzatoğlu B, Hatipoğlu E, Bayramoğlu S, Yllmaz G, Yirik G, Cimili T. Comparison of ultrasonographic and computed tomographic findings in the diagnosis of acute apendicitis. Med J Bakirkoy 2006;2;22-4.

2. Doğan S, Bulut AŞ, Karamürsel BS. A rare differential diagnosis of acute appendicitis: Appendiceal endometriosis. Turk J Surg 2012;28;159-61.

3. Lowry SF, Hong JJ. Appendicitis and appendiceal abscess In: Fischer JE, editor. Mastery of surgery. 5th ed. Philadelphia: Lippincott Williams \& Wilkins; 2007.p. 1430-43.

4. Alvarado A. A practical score for the early diagnosis of acute appendicitis. Ann Emerg Med 1986;15:557-64.

5. Yildirim E, Karagülle E, Kirbaş I, Türk E, Hasdoğan B, Tekşam M, et al. Alvarado scores and pain onset in relation to multislice CT findings in acute appendicitis. Diagn Interv Radiol 2008;14:14-8.

6. Yüksel Y, Dinç B, Yüksel D, Dinç SE, Mesci A. How reliable is the Alvarado score in acute appendicitis? Ulus Travma Acil Cerrahi Derg 2014;20:12-8.

7. Kaya B, Sana B, Eris C, Karabulut K, Bat O, Kutanis R. The diagnostic value of $\mathrm{D}$-dimer, procalcitonin and CRP in acute appendicitis. Int J Med Sci 2012;9:909-15.

8. Peltola H, Ahlqvist J, Rapola J, Räsänen J, Louhimo I, Saarinen M, et al. C-reactive protein compared with white blood cell count and erythrocyte sedimentation rate in the diagnosis of acute appendicitis in children. Acta Chir Scand 1986;152:55-8.

9. Mengücük ME, Ayten R, Bülbüller N, Gödekmerdan A, Başbuğ M, Mungan İ. Role of C-reactive Protein, Procalsitonin and Neopterin in the Diagnosis of Acute Appendicitis. Firat Tip Dergisi 2010;15:40-3.
10. Fuchs D, Weiss G, Reibnegger G, Wachter $H$. The role of neopterin as a monitor of cellular immune activation in transplantation, inflammatory, infectious, and malignant diseases. Crit Rev Clin Lab Sci 1992;29:30741.

11. Phoprom J, Trivej T. The Modified Alvarado Score Versus the Alvarado Score for the Diagnosis of Acute Appendicitis. Thai J Surg 2005;26:6972 .

12. Menteş Ö, Eryılmaz M, Yiğit T, Taşc1 S, Balkan M, Kozak O, et al. Retrospectively analysis of appendectomies which performed elderly cases. [Article in Turkish] EAJEM 2008;7:36-41.

13. Memon AA, Vohra LM, Khalig T, Lehri AA. Diagnostic Accururacy of Alvarado Score in the Diagnosis of Acute Appendicitis. Pak J Med Sci 2009;25:118-21.

14. Douglas CD, Macpherson NE, Davidson PM, Gani JS. Randomised controlled trial of ultrasonography in diagnosis of acute appendicitis, incorporating the Alvarado score. BMJ 2000;321:919-22.

15. Winn RD, Laura S, Douglas C, Davidson P, Gani JS. Protocol-based approach to suspected appendicitis, incorporating the Alvarado score and outpatient antibiotics. ANZ J Surg 2004;74:324-9.

16. Khan I, ur Rehman A. Application of alvarado scoring system in diagnosis of acute appendicitis. J Ayub Med Coll Abbottabad 2005;17:41-4.

17. Uzunköy A, Akıncı ÖF, Coşkun A, Karamanoğlu M, Erdoğan M. The role ultrasonographic investigation in the diadnosis of akut Appendicitis. Ulus Travma Acil Cerrahi Derg 1998;4:202-5.

18. Wu HP, Lin CY, Chang CF, Chang YJ, Huang CY. Predictive value of C-reactive protein at different cutoff levels in acute appendicitis. Am J Emerg Med 2005;23:449-53.

19. Albu E, Miller BM, Choi Y, Lakhanpal S, Murthy RN, Gerst PH. Diagnostic value of C-reactive protein in acute appendicitis. Dis Colon Rectum 1994;37:49-51.

20. Mikaelsson C, Arnbjörnsson E. The value of C-reactive protein (CRP) determinations in patients with suspected acute appendicitis. Ann Chir Gynaecol 1984;73:281-4.

21. Yang HR, Wang YC, Chung PK, Chen WK, Jeng LB, Chen RJ. Laboratory tests in patients with acute appendicitis. ANZ J Surg 2006;76:71-4.

22. Yildirim O, Solak C, Koçer B, Unal B, Karabeyoğlu M, Bozkurt B, et al. The role of serum inflammatory markers in acute appendicitis and their success in preventing negative laparotomy.J Invest Surg 2006;19:345-52.

23. Pruekprasert P, Maipang T, Geater A, Apakupakul N, Ksuntigij P. Accuracy in diagnosis of acute appendicitis by comparing serum $\mathrm{C}$-reactive protein measurements, Alvarado score and clinical impression of surgeons. J Med Assoc Thai 2004;87:296-303.

24. Wu JY, Chen HC, Lee SH, Chan RC, Lee CC, Chang SS. Diagnostic role of procalcitonin in patients with suspected appendicitis. World J Surg 2012;36:1744-9. 
ORİJiNAL ÇALIŞMA - ÖZET

\section{Akut apandisit tanısında Alvarado skorlaması, C-reaktif protein, prokalsitonin ve neopterin biyolojik belirteçlerin yeri \\ Dr. Fatih Dal, ${ }^{1}$ Dr. Yusuf Çiçek, ${ }^{2}$ Dr. Salih Pekmezci, ${ }^{2}$ Dr. Bekir Kocazeybek, ${ }^{3}$ Dr. Hrisi Bahar Tokman, ${ }^{3}$ Dr. Dildar Konukoğlu, ${ }^{4}$ Dr. Osman Şimşek, ${ }^{2}$ Dr. Zeynep Taner, ${ }^{3}$ Dr. Serhat Sirekbasan, ${ }^{3}$ Dr. Server Sezgin Uludağ ${ }^{2}$}

1Sağlık Bilimleri Üniversitesi, İstanbul Eğitim ve Araştırma Hastanesi, Genel Cerrahi Kliniği, İstanbul
2'Istanbul Üniversitesi-Cerrahpaşa, Cerrahpaşa Tıp Fakültesi, Genel Cerrahi Anabilim Dalı, İstanbul
${ }^{3}$ İstanbul Üniversitesi-Cerrahpaşa, Cerrahpaşa Tıp Fakültesi, Tıbbi Mikrobiyoloji Anabilim Dalı, İstanbul
${ }^{4}$ İstanbul Üniversitesi-Cerrahpaşa, Cerrahpaşa Tıp Fakültesi, Tıbbi Biyokimya Anabilim Dalı, İstanbul

AMAÇ: Akut apandisit (AA), günümüzde hala kesin tanısını koymak mümkün değildir. Tanıdaki gecikmeler, komplikasyon oranlarını artırmaktadır. Alvarado skorlaması (AS) ve biyolojik belirteçlerin (C-reaktif protein [CRP], prokalsitonin [PCT], neopterin [NP]) tek ve AS ile birlikte kullanılmalarının tanıya olan katkılarının araştırılması amaçlandı.

GEREÇ VE YÖNTEM: İstanbul Üniversitesi Cerrahpaşa Tıp Fakültesi, Genel Cerrahi Kliniği'ne, 04.03.2014-29.07.20।5 tarihleri arasında, AA ön tanısıyla, gönüllü 100 hastadan, yatış öncesi serumları alınarak -70 derecede saklandı. Hastalar, AA pozitif ( $n=60$ ), negatif ( $n=40)$ gruplandı. AA pozitif grup; komplike $(n=1$ I), nonkomplike $(n=49)$ olarak gruplandırılarak, AS, CRP, PCT ve NP değerleri karşılaştırıldı.

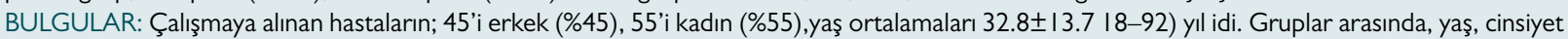
açısından anlamlı fark yoktu. AS dağıımı; AS $\leq 4$ ( $n=24)$ üçü, AS 5-7 (no: 35) 22'si, AS 8-I0 (no: 4I) 38'i ameliyat edildi. Ameliyat edilen 63 hastanın üçünde normal apendiks saptandı. AA pozitif ve negatif grupların, serum CRP, PCT, NP değerlerinin tanıda yetersiz olduğu ancak AS'nin sensivite ve duyarlılığını artırdığı görüldü. Biyolojik belirteçlerin ortalaması karşılaştırıldığında; komplike $A A$ grup ayrımında anlamlıydı ( $P<0.05$ ).

TARTIŞMA: Alvarado skorlaması, iyi bir skorlama olmasına karşın, ek inceleme ve klinik yaklaşımlara ihtiyaç vardır. Serum CRP, PCT ve NP değerleri, tek başlarına, AA tanısında yetersizdir. Ancak AS'nin değerini arttırmakta ve komplike AA olgularını ayırmada yararılıdır.

Anahtar sözcükler: Akut apandisit; Alvarado skorlaması; C-reaktif protein; neopterin; prokalsitonin.

Ulus Travma Acil Cerrahi Derg 2019;25(3):229-237 doi: 10.5505/tjtes.2018.57362 